\title{
Assessing the Impacts of Land Use and Land Cover Changes on Hydrology of the Mbarali River Sub-Catchment. The Case of Upper Great Ruaha Sub-Basin, Tanzania
}

\author{
Edmund Mutayoba1,2, Japhet J. Kashaigili3 ${ }^{3}$, Frederick C. Kahimba², Winfred Mbungu², \\ Nyemo A. Chilagane ${ }^{3}$ \\ ${ }^{1}$ Department of Built Environmental Engineering, Mbeya University of Science and Technology, Mbeya, Tanzania \\ ${ }^{2}$ Department of Engineering Science and Technology, Sokoine University of Agriculture, Morogoro, Tanzania \\ ${ }^{3}$ Department of Forest Resource Assessment and Management, Sokoine University of Agriculture, Morogoro, Tanzania \\ Email: Edmuta27@gmail.com
}

How to cite this paper: Mutayoba, E., Kashaigili, J.J., Kahimba, F.C., Mbungu, W. and Chilagane, N.A. (2018) Assessing the Impacts of Land Use and Land Cover Changes on Hydrology of the Mbarali River Sub-Catchment. The Case of Upper Great Ruaha Sub-Basin, Tanzania. Engineering, 10, 616-635.

https://doi.org/10.4236/eng.2018.109045

Received: August 6, 2018

Accepted: September 26, 2018

Published: September 29, 2018

Copyright $\odot 2018$ by authors and Scientific Research Publishing Inc. This work is licensed under the Creative Commons Attribution International License (CC BY 4.0).

http://creativecommons.org/licenses/by/4.0/

\begin{abstract}
Intensification of agricultural land use and population growth from 1990-2017 has caused changes in land cover and land use of the Mbarali River sub-catchment which is located in the Upper Great Ruaha Sub basin, Tanzania. This has affected the magnitude of the surface runoff, total water yield and the groundwater flow. This study assesses the impacts of the land cover and land use changes on the stream flows and hydrological water balance components (surface runoff, water yield, percolation and actual evapotranspiration). The land use and land cover (LULC) maps for three window period snapshots, 1990, 2006 and 2017 were created from Landsat TM and OLI_TIRS with the help of QGIS version 2.6. Supervised classification was used to generate LULC maps using the Maximum Likelihood Algorithm and Kappa statistics for assessment of accuracy. SWAT was set up and run to simulate stream flows and hydrological water balance components. The assessment of the impacts of land use and land cover changes on stream flows and hydrological water balance component was performed by comparing hydrological parameters simulated by SWAT using land use scenarios of 2006 and 2017 against the baseline land use scenario of 1990. Accuracy of LULC classification was good with Kappa statistics ranging between 0.9 and 0.99 . There was a drastic increase in areal coverage of cultivated land, for periods 1990-2006 (5.84\%) and 2006-2017 (12.05\%) compared to other LULC. During 2006 and 2017 surface runoff increased by $4 \%$ and $9 \%$ respectively; however, water yield increased by only $0.5 \%$ compared to 1990 baseline period. This was attributed to increased proportion of cultivated land in the
\end{abstract}


sub-catchment which has a high curve number (59.60) that indicates a higher runoff response and low infiltration rate.

\section{Keywords}

Geographic Information System (GIS), Mbarali River Sub-Catchment, Land Use and Cover Change, Soil and Water Assessment Tool (SWAT), Water Balance, Stream Flow

\section{Introduction}

Many studies in African countries have revealed a decline in availability of water and agricultural productivity within catchments [1]. This decline is partly caused by changes in land use and land cover [2]. Land use and land cover are key variables in managing most of the hydrological models for large and even smaller river catchments. A study conducted by [3] revealed that land use and land cover changes (e.g., change of forestland to agricultural land or built area) have a serious effect on the rate of surface runoff, groundwater recharge, erosion and sediment transport. Since land use change has a significant and profound effect on water quality and quantity, there is an urgent need to understand the interaction between land use change, hydrology and water resources management [4] [5]. Several studies [6] [7] have discovered that deforestation or afforestation can cause decrease or increase in total water yield. This has been detected in catchments with wide-ranging area spreading from a smaller than $1 \mathrm{~km}^{2}$ to more than $1000 \mathrm{~km}^{2}[8]$.

Tanzania, like other countries, has been experiencing frequent alteration of land use as a result of several factors such as population growth, climatic variability, and national policies. In previous years, land cover and land use changes induced by human population pressure and rainfall variability have adversely affected the condition of water resources in the Great Ruaha Sub-catchment of the Rufiji Basin [9]. A study by [10] discovered that land modifications in the Upper Great Ruaha resulted in decreased base flows, high peak stream flows, increased width of river channel, and sediment accumulation along the riverbed. This study used remote sensing as the only technique to investigate the hydrological impacts of land use and land cover changes on flow regimes of the Great Ruaha River. The study was unable to integrate hydrological model and land use land cover changes detection technique to evaluate the impacts of land use and land cover changes on the hydrology and water balance of the catchment. The present study sought to integrate quantum geographical information system (QGIS), semi-distributed soil and water assessment tool (SWAT) model to quantify the extent and impacts of land use and land cover changes on river flow in the Mbarali River sub-catchment between 1990 and 2017.

Mbarali River sub-catchment experiences rapid population growth, with an annual growth rate of $3.1 \%$ compared to the national annual growth rate of $2.7 \%$ 
[11]. This has resulted into the expansion of built-up area and agricultural land. Consequently, it has impacted the water balance of the river sub-catchment by changing the magnitude and pattern of the components of stream flow such as surface runoff and ground water flow, resulting into increased extent of water management problems. Regardless of what is so far known about threats on Mbarali River Sub-catchment, little effort has been made to understand the effects of land use and land cover changes on hydrology and water balance in the river sub-catchment. This calls for the need to understand the extent to which alterations of the land use and land cover have impacted on water availability in this river sub-catchment. Assessing the impact of land use and land cover changes on hydrology is very important for current and future management of Mbarali River Sub-catchment and other catchments in Tanzania.

\section{Material and Method}

\subsection{Description of the Study Area}

The Mbarali river sub-catchment (Figure 1) is located between latitude $7^{\circ} \mathrm{S}$ and $9^{\circ} \mathrm{S}$ and between longitude $33.8^{\circ} \mathrm{E}$ and $35^{\circ} \mathrm{E}$ in the upper Great Ruaha sub basin

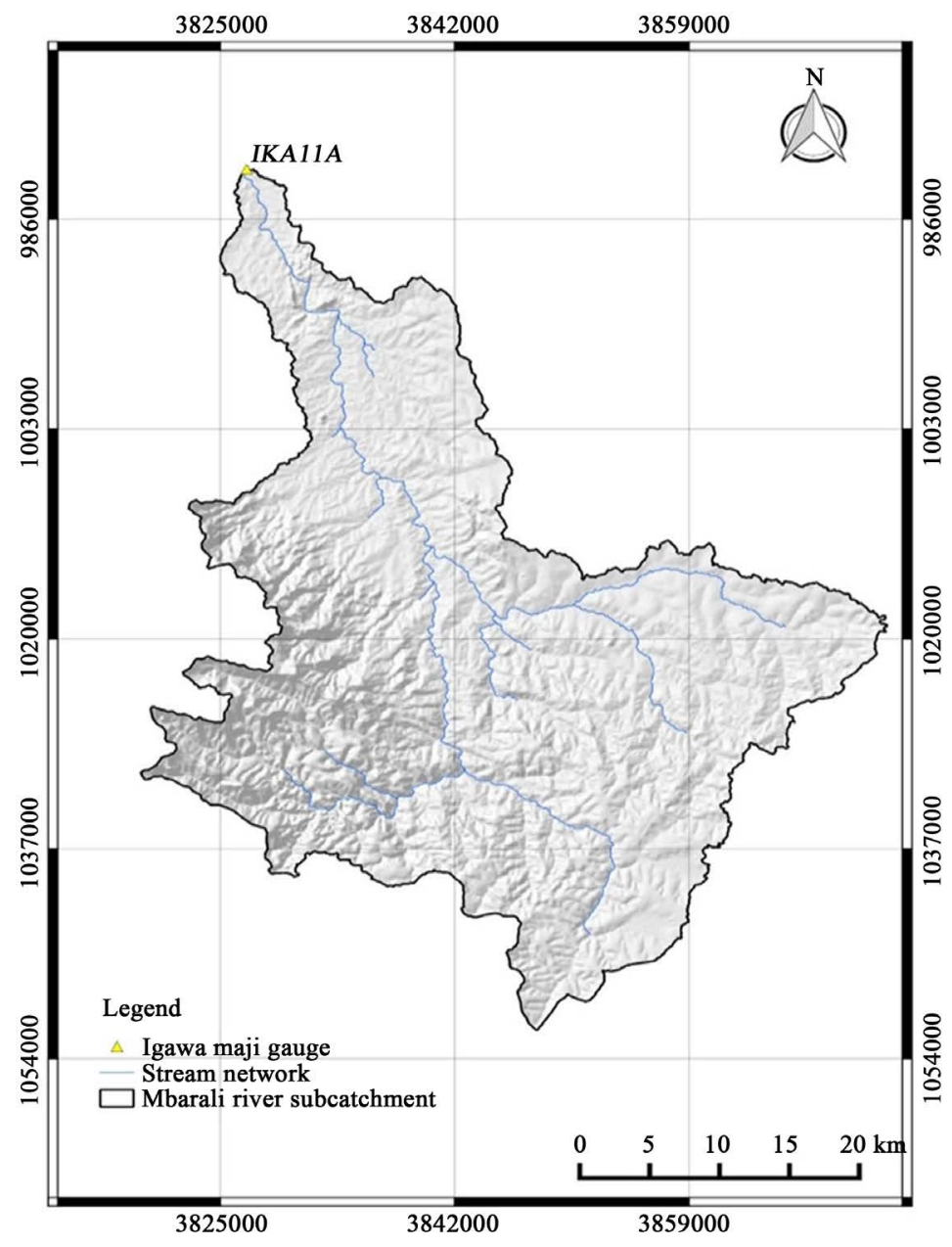

Figure 1. Map of the study area. 
of the Rufiji basin in the southern highlands of Tanzania. The population of Mbarali depends mainly on subsistence agriculture and livestock keeping for livelihoods. The River catchment has a total area of $1530 \mathrm{sq} \mathrm{km}$, of which 321,500 ha are arable land that have potential for agriculture production and currently 187,600 ha have been developed (NBS, 2012). Paddy production becomes the main food/cash crop which makes Mbarali to become one of the main paddy producers and exporters in Tanzania and neighboring countries. Other crops which are also grown include maize, sweat potatoes, sorghum, sunflower, onions, cassava, beans, groundnuts and vegetables (Mbarali District Profile 2016). Apart from rain fed agriculture the river catchment also undertakes agriculture irrigation farming and paddy being the main crop cultivated at large scale under irrigation. The district has the total of 44,000 (Ha) cultivated under irrigation which is equivalent to $13.7 \%$ of the total arable land potential for agriculture. The sub-catchment is at an altitude ranging from 1000 to 1800 meters above sea level, and its average temperature ranges between $25^{\circ} \mathrm{C}$ and $30^{\circ} \mathrm{C}$, while its mean annual rainfall is about 450 to $650 \mathrm{~mm}$.

\subsection{Method}

Data collected and used in this study included spatial data, hydrological data and meteorological data. Spatial data include satellite images and $30 \mathrm{~m}$ resolution digital elevation model (DEM) downloaded from USGS-GLOVIS [12] and NASA reverb [13] respectively. Meteorological data comprised rainfall, relative humidity, solar radiation and wind speed. The minimum and maximum temperature data were obtained from Tanzania Meteorological Agency and Rufiji Basin Water Office, Iringa. River discharge data for the year 1990-2010 were used in this study and obtained from Igawa maji gauging station (IKA11A).

\subsubsection{Data Analysis}

The land cover change detection analysis was conducted to assess and quantify spatial and temporal changes in land use and land cover in Mbarali sub-catchment. Appropriate satellite imagery acquisition was done with a higher consideration of cloud cover, the seasonality and phenological effects [14]. Clouds free satellite images with less than $10 \%$ clouds cover were selected for this study.

To ensure accurate identification of temporal changes and geometric compatibility with other sources of information, images were pre-processed whereby geo-correction was conducted to rectify precisely matching of images (refer Table 2). Band stacking and Images enhancement was performed using different color composite band combination and its contrast was stretched from minimum to maximum to reinforce the visual interpretability of images. Images were registered to the UTM map coordinate system, Zone 36 South, Datum Arc 1960. Image Mosaic was conducted to merge together images of the same year with same path and different row (refer Table 1) so as to create a single image that covers the entire catchment. Supervised image classification using Maximum Likelihood Classifier (MLC) was conducted to create a base map. 
Table 1. Satellite imagery data.

\begin{tabular}{cccccc}
\hline Year & Spacecraft & Sensor_ID & Path/Row & $\begin{array}{c}\text { Acquisition date } \\
\text { (mm-dd-yy) }\end{array}$ & $\begin{array}{c}\text { Cloud } \\
\text { clover (\%) }\end{array}$ \\
\hline \multirow{2}{*}{1990} & Landsat 5 & TM (SAM) & $168 / 66$ & $11 / 07 / 90$ & 1 \\
& Landsat 5 & TM (SAM) & $169 / 66$ & $10 / 06 / 90$ & 1 \\
\multirow{2}{*}{2006} & Landsat 5 & TM (BUMPER) & $168 / 66$ & $09 / 06 / 05$ & 5 \\
& Landsat 5 & TM (BUMPER) & $169 / 66$ & $09 / 16 / 06$ & 1 \\
\hline \multirow{2}{*}{2017} & Landsat 8 & OLI_TIRS & $168 / 66$ & $22 / 10 / 2016$ & 1.59 \\
\hline
\end{tabular}

Ground truthing data were used to formulate and confirm different cover classes existing in the study area (refer Table 2). Training sites were identified by inspecting an enhanced color composite imagery. Areas with similar spectral characteristics were trained and classified. Supervised classification by using Semi-automatic Classification Plug in (SCP) available in QGIS version 2.2 was conducted and a maximum of seven dissimilar land cover classes were identified (refer Table 2).

\subsubsection{Image Classification and Accuracy Assessment}

User accuracy, producer's accuracy and Kappa coefficient statistics $(K)$ was used to assess the accuracy of final image classification

$$
K=\frac{N \sum_{i=1}^{r} x_{i i}-\sum_{i=1}^{r}\left(x_{i+} \times x_{+i}\right)}{N^{2}-\sum_{i=1}^{r}\left(x_{i+} \times x_{+i}\right)}
$$

where $N$ is the total number of sites in the matrix, $r$ is the number of rows in the matrix, $x_{i i}$ is the number in row $i$ and column $i, X_{+i}$ is the total for row $i$, and $x_{i+}$ is the total for column.

Post classification comparison was used to quantify the extent of land cover changes over the period 1990, 2006 and 2017. Post classification comparison bypass the difficulties associated with the analysis of the images that are acquired at different times of the year, or by different sensors and results of high change detection accuracy [15]. The estimation of the rate of change for the different land covers was computed based on the following formulas [10].

$$
\begin{gathered}
\% \text { Cover change }=\frac{\text { Area }_{i \text { year } x}-\text { Area }_{i \text { year } x+1}}{\sum_{i=1}^{n} \text { Area }_{i \text { year } x}} \times 100 \\
\text { Annual rate of change }=\frac{\text { Area }_{i \text { year } x}-\text { Area }_{i \text { year } x+1}}{t_{\text {years }}} \\
\% \text { Annual rate of change }=\frac{\text { Area }_{i \text { year } x}-\text { Area }_{i \text { year } x+1}}{\text { Area }_{i \text { year } x} \times t_{\text {years }}} \times 100
\end{gathered}
$$

Area $_{i \text { year } x}$ is the area of cover $i$ at the first date,

Area $_{i \text { year } x+1}$ is the area of cover $i$ at the second date,

$\sum_{i=1}^{n} A_{\text {rea }}{ }_{i \text { year } x}$ is the total cover area at the first date,

$t_{\text {years }}$ is the period in years between the first and second scene acquisition dates. 
Table 2. Land use/cover classification scheme.

\begin{tabular}{|c|c|}
\hline Land cover class & Description \\
\hline Forest & $\begin{array}{l}\text { Land covered with naturally regenerated native tree species } \\
\text { with no clearly visible indications of human activities }\end{array}$ \\
\hline Wetland & Land area that is saturated with water either permanent or seasonally \\
\hline Woodland & $\begin{array}{l}\text { Area of land covered low density trees forming open habitat with } \\
\text { plenty of sunlight and limited shade }\end{array}$ \\
\hline Grassland & Land area dominated by grasses \\
\hline Bushland & Area dominated with bushes and shrubs \\
\hline Cultivated land & Farm with crops and harvested cropland \\
\hline Built up area & Man-made infrastructure (roads and buildings) and settlement \\
\hline
\end{tabular}

\subsection{Hydrological Model}

The study used the Soil and Water Assessment Tool (SWAT) model to simulate the effects of land use and land cover changes on stream flow. The calibrated SWAT model was run with the input data including digital elevation model (DEM), soil data, land use data, rainfall, and stream flow. The following steps were conducted during SWAT model set up. The first step was to delineate the sub-catchment by splitting the catchment into sub-basins according to the terrain model and river channels. QSWAT 2012, a QGIS interface, was used to delineate the sub-catchment. HRUs were generated based on user-defined threshold percentages [16]. Before defining the HRUs, the land use data were reclassified to match with the SWAT land use classification. Land use and soil data were required in SWAT model to determine the area and the hydrologic parameters of each land-soil categories simulated within each sub-catchment. Input data (climatic data) were prepared, edited and saved into delimited format so that they can be read in SWAT.

\subsubsection{Sensitivity and Uncertainty Analysis}

To understand how closely the model simulates the hydrological processes within a sub-catchment, it is critical to examine the influence of different parameters. Sensitivity analysis is the computation of the most sensitive parameters for a given sub-catchment. In this study a sensitivity analysis using the Sequential Uncertainty Fitting (SUFI-2) within the SWAT-CUP model [17] was used. The advantage of using SWAT-CUP relies on the possibility of using different kinds of parameters including those responsible for surface runoff, water quality parameters, crop, parameters, crop rotation and management parameters, and weather generator parameters [16].

\subsubsection{Most Sensitive Parameters and Their Fitted Values}

SWAT CUP 2012 software was used for SWAT model sensitivity analysis, calibration and validation. This software has been applied in a number of studies and is gaining popularity worldwide. Its advantageous features are a user-friendly interface, linkage with the QSWAT model run results, simplicity re- 
garding execution, and semi-automated process for the selection of best basin parameter ranges. Before calibration, a sensitivity analysis was performed in the selection of the most sensitive hydrological parameters. The best parameters which give the best value of the objective function were used in the current study. The average monthly stream flow data of 16 years from 1990 to 2005 of the Igawa Maji gauging station were used to compute the sensitivity of the stream flow parameters.

\subsubsection{Model Calibration and Validation}

Calibration was conducted daily and was done for 16 years from 1990 to 2005, 5 years prior to 1990 were used for warm up period which was intended to allow the model parameters to reach a stable state conditions. Validation period was set for 5 years period from 2006 to 2010 . The calibration and validation processes were carried out using the Sequential Uncertainty Fitting (SUFI-2).

\subsubsection{Simulation Analysis}

The calibrated model was then used to simulate stream flows under changed land-use/cover conditions for the year 1990, 2006 and 2017, while maintaining the same weather data. The influences of the land use and land cover changes on stream flows were quantified by comparing output of the SWAT hydrological model (Observed and Simulated) for the time period 1990, 2006, 2017. The differences between the observed and simulated discharge under changed land use and land cover represent the effects of land use and land cover changes on hydrological responses in the catchment.

\section{Results and Discussion}

\subsection{Land Use and Land Cover Changes over the Mbarali River Sub-Catchment}

Figure 2 below presents the variations in land use and land cover maps of the Mbarali River Sub-catchment during the year 1990, 2006 and 2017, while Table 3 shows the comparison of classification of the Land use/cover from Landsat

Table 3. Comparison of the LULC of the year 1990, 2006 and 2017.

\begin{tabular}{ccccccc}
\hline \multirow{2}{*}{ Year } & \multicolumn{2}{c}{1990} & \multicolumn{2}{c}{2006} & \multicolumn{2}{c}{2017} \\
\cline { 2 - 7 } & $(\mathrm{Ha})$ & $(\%)$ & $(\mathrm{Ha})$ & $(\%)$ & $(\mathrm{Ha})$ & $(\%)$ \\
\hline Forest & 11,348 & 7.54 & 8292 & 5.51 & 7871 & 5.23 \\
Woodland & 34,791 & 23.13 & 35,327 & 23.08 & 24,453 & 16.26 \\
Bushland & 55,132 & 36.65 & 46,279 & 30.77 & 42,657 & 28.36 \\
Grassland & 10,367 & 6.89 & 12532 & 8.33 & 9224 & 6.13 \\
Wetland & 92 & 0.06 & 53 & 0.04 & 125 & 0.08 \\
Cultivated land & 38,648 & 25.69 & 47,426 & 31.53 & 65,547 & 43.57 \\
Built up area & 45 & 0.03 & 514 & 0.34 & 547 & 0.36 \\
Total & 150,424 & 100 & 150,424 & 100 & 150,424 & 100 \\
\hline
\end{tabular}



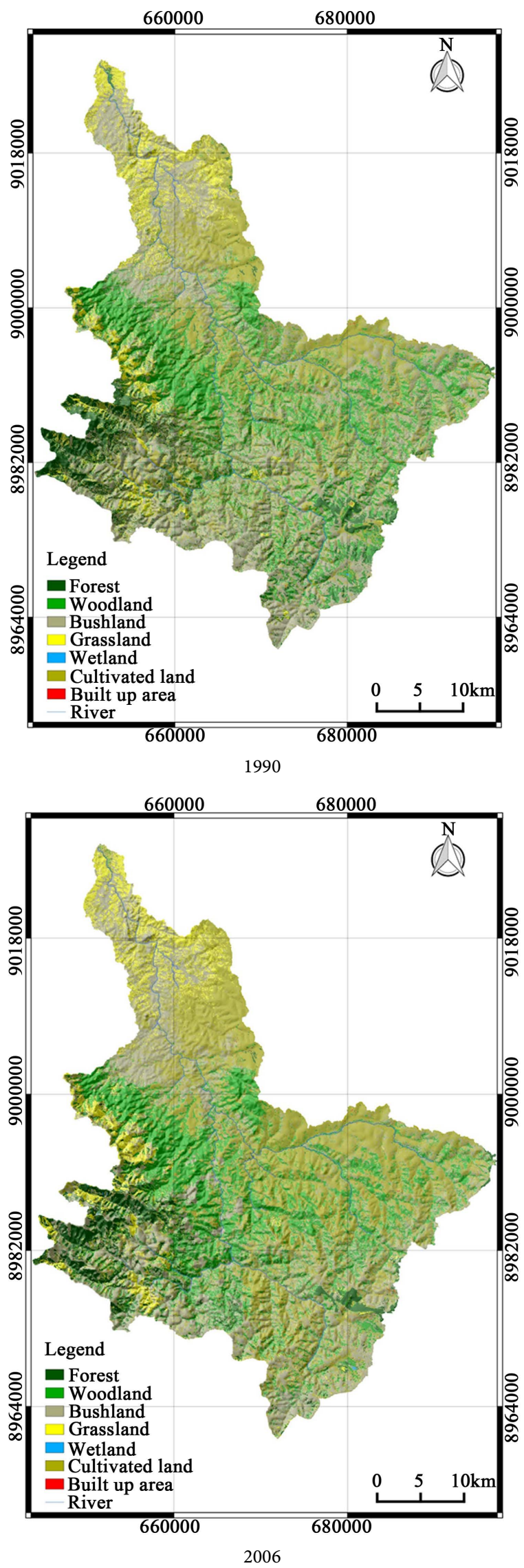


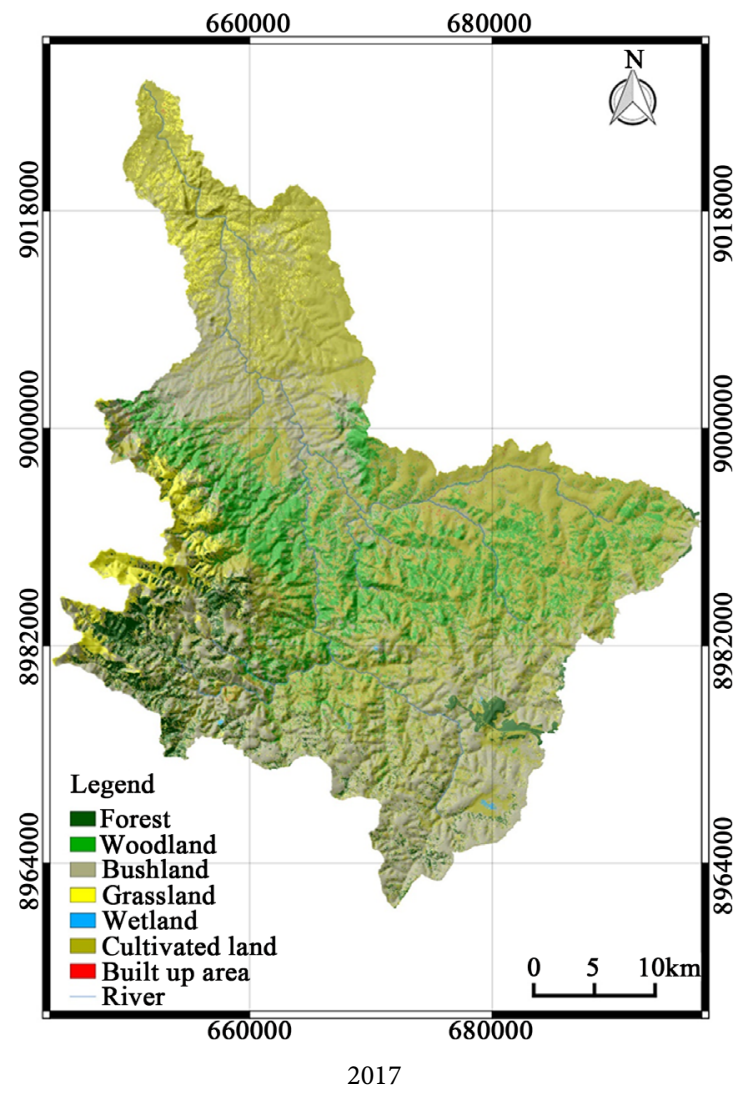

Figure 2. Land use/cover maps for 1990, 2006 and 2017.

1990, 2006 and 2017, i.e. a complete number of pixels and percentage number of all pixels. Forest, woodland, Bushland, Grassland, wetland, cultivated land and Built up area are the major land covers classes. In 1990, 36.65\% of all image pixels were classified as Bushland, $25.69 \%$ as cultivated land, $23.13 \%$ as woodland, $7.54 \%$ as forest, $6.89 \%$ as Grassland and the Built-up area was $0.03 \%$. In more than 18 years later, the land cover classes had changed as follows: $5.23 \%$ forest, $16.26 \%$ woodland, $28.36 \%$ bushland, $6.13 \%$ grassland, $43.57 \%$ cultivated land and $0.36 \%$ built up area.

\subsection{Change in Land Use and Land Cover for the Year 1990-2006, and from 2006-2017}

Table 4 presents the land use and land cover area distribution for the window period 1990-2006 and 2006-2017. From the table it is shown that, the land use and land cover areas within the Mbarali River catchment are mostly occupied by cultivated land. In the year 1990, it was found to occupy 38,648 ha, and in 2006 , it had 47,426 ha, while in the year 2017 had 65,547 ha. The cultivated land has been increasing for more than 10 years. The results also indicate that, for the two-window period between 1990-2006 and 2006-2017 the area under natural forest was found to decrease by 3056 ha (2.03\%) and decreased by 421 ha (0.28\%), Bushland decrease by 8853 ha (5.89\%) and 3622 ha (2.41\%) respectively. 
Table 4. Land use and land cover area distribution.

\begin{tabular}{|c|c|c|c|c|c|c|c|c|c|}
\hline \multirow[b]{2}{*}{ LULC } & \multirow{2}{*}{$\begin{array}{l}1990 \\
\mathrm{Ha}\end{array}$} & \multirow{2}{*}{$\begin{array}{l}2006 \\
\mathrm{Ha}\end{array}$} & \multirow{2}{*}{$\begin{array}{c}2017 \\
\mathrm{Ha}\end{array}$} & \multicolumn{3}{|c|}{$1990-2006$} & \multicolumn{3}{|c|}{$2006-2017$} \\
\hline & & & & $\begin{array}{c}\text { Area } \\
\text { change } \\
(\mathrm{Ha})\end{array}$ & $\begin{array}{c}\text { Percentage } \\
\text { change } \\
(\%)\end{array}$ & $\begin{array}{l}\text { Annual } \\
\text { Rate of } \\
\text { Change } \\
\text { (Ha/year) }\end{array}$ & $\begin{array}{c}\text { Area } \\
\text { change } \\
\text { (Ha) }\end{array}$ & $\begin{array}{c}\text { Percentage } \\
\text { change } \\
(\%)\end{array}$ & $\begin{array}{l}\text { Annual } \\
\text { Rate of } \\
\text { Change } \\
\text { (Ha/year) }\end{array}$ \\
\hline Forest & 11,348 & 8292 & 7871 & -3056 & -2.03 & -191 & -421 & -0.28 & -38 \\
\hline Woodland & 34,791 & 35,327 & 24,453 & 536 & 0.36 & 33 & $-10,874$ & -7.23 & -989 \\
\hline Bushland & 55,132 & 46,279 & 42,657 & -8853 & -5.89 & -553 & -3622 & -2.41 & -329 \\
\hline Grassland & 10,367 & 12,532 & 9224 & 2165 & 1.44 & 135 & -3308 & -2.20 & -301 \\
\hline Wetland & 92 & 53 & 125 & -39 & -0.03 & -2 & 72 & 0.05 & 7 \\
\hline $\begin{array}{c}\text { Cultivated } \\
\text { land }\end{array}$ & 38,648 & 47,426 & 65,547 & 8778 & 5.84 & 549 & 18,121 & 12.05 & 1647 \\
\hline $\begin{array}{c}\text { Built Up } \\
\text { area }\end{array}$ & 45 & 514 & 547 & 469 & 0.31 & 29 & 33 & 0.02 & 3 \\
\hline Total & 150,424 & 150,424 & 150,424 & & & & & & \\
\hline
\end{tabular}

The decrease in Hectares in forest for the two-window period is due to the demand of land for agricultural activities, since agriculture is the main activity undertaken within the study area.

Similarly, Built-up area shows an increase of 469 ha $(0.31 \%)$ by the period of 1990-2006 and increase by 33 ha (0.02\%) for the year 2006-2017. The built-up area was found to increase at the rate of $29 \mathrm{ha} /$ year $(0.31 \% / y e a r)$ and $3 \mathrm{ha} /$ year (0.02\%/years) for the two-window period, between 1990-2006 and 2006-2017 respectively. The cultivated land had increased by 549 ha/year (5.84\%) for the period 1990-2006 and an increase of 1647 ha/year for the period of 2006-2017. This fast increase might be due to the expansion of agricultural land and settlement to withstand the living of local people and probably the need for the firewood.

\subsection{Change Detection and Post-Classification of Different Land Use/Cover}

Tables 5 and Table 6 present change detection of different land cover maps. A confusion matrix method was used to map the land cover changes for the two-window period 1990-2006 and 2006-2017. The results for the change confusion matrix of the LU/LC (Table 5 \& Table 6) show an increase in the cultivated land by $60.85 \%$, grassland increased by $23.2 \%$, and there was no increase in Built up area. Also, the results revealed the decrease in the forest (16.2\%) and the woodland (13.5\%). Figure 3 also depicts the number of hectares occupied by the LU/LC for the two-window period. It is revealed that cultivated land has changed significantly in both study periods which resulted in the formation of wetlands (water bodies) as compare to year 1990-2006 when there were no wetlands. 


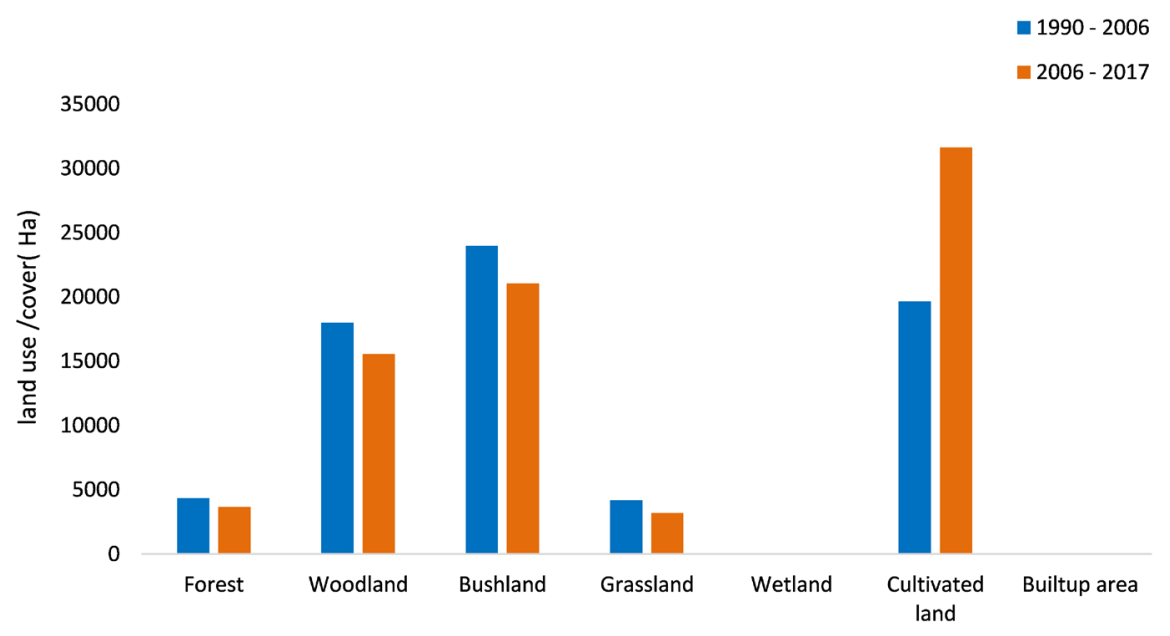

Figure 3. Comparison between land use and land cover changes for 1990-2006 and 2006-2017.

Table 5. Confusion matrix for land use/land cover (1990-2006).

\begin{tabular}{cccccccccc}
\hline LULC (ha) & Forest & \multicolumn{2}{c}{ Woodland Bushland Grassland } & Wetland & \multicolumn{2}{c}{$\begin{array}{c}\text { Cultivated } \\
\text { land }\end{array}$} & $\begin{array}{c}\text { Built-up } \\
\text { area }\end{array}$ & TOTAL \\
\hline Forest & 4347 & 1753 & 2829 & 1173 & 25 & 1308 & 57 & 11,492 \\
Woodland & 736 & 17,995 & 6981 & 1424 & 5 & 7515 & 126 & 34,782 \\
Bushland & 1640 & 8352 & 23,990 & 4197 & 4 & 16,692 & 177 & 55,052 \\
Grassland & 207 & 701 & 3105 & 4175 & 0 & 2138 & 14 & 10,339 \\
Wetland & 12 & 38 & 34 & 3 & 0 & 4 & 0 & 92 \\
Cultivated land & 1526 & 6473 & 9282 & 1529 & 19 & 19,658 & 135 & 38621 \\
Builtup area & 2 & 4 & 8 & 2 & 0 & 25 & 4 & 45 \\
TOTAL & 8470 & 35,317 & 46,229 & 12,502 & 53 & 47,339 & 513 & 15,0424 \\
\hline
\end{tabular}

Table 6. Confusion matrix for land use/land cover (2006-2017).

\begin{tabular}{cccccccccc}
\hline $\begin{array}{c}\text { LULC } \\
\text { (ha) }\end{array}$ & Forest & Woodland Bushland Grassland & Wetland & $\begin{array}{c}\text { Cultivated } \\
\text { land }\end{array}$ & $\begin{array}{c}\text { Built Up } \\
\text { area }\end{array}$ & TOTAL \\
\hline Forest & 3642 & 388 & 1590 & 1166 & 22 & 1451 & 33 & 8292 \\
Woodland & 1097 & 15,560 & 8357 & 433 & 40 & 9649 & 190 & 35,327 \\
Bushland & 2119 & 2455 & 21,047 & 3203 & 34 & 17,326 & 97 & 46,279 \\
Grassland & 480 & 634 & 2943 & 3189 & 17 & 5232 & 37 & 12,532 \\
Wetland & 1 & 0 & 23 & 20 & 2 & 9 & 0 & 53 \\
Cultivated land & 501 & 5359 & 8551 & 1198 & 10 & 31621 & 185 & 47,426 \\
Builtup area & 31 & 57 & 147 & 16 & 0 & 258 & 4 & 514 \\
TOTAL & 7871 & 24,453 & 42,657 & 9224 & 125 & 65,547 & 547 & 150,424 \\
\hline
\end{tabular}




\subsection{Change Detection Accuracy}

The results of supervised classification of ETM and satellite imagery were evaluated for the study area. The overall classification accuracy and Kappa Coefficient were computed to provide measures of accuracy of the classification. The producer's and user's accuracy were calculated to assess error patterns of the respective classification.

Table 7 shows the result of supervised classification of ETM data of the years 1990, 2006 and 2017. The Kappa Coefficient took a value of 0.9, 0.95 and 0.99 and the overall accuracy was found to increase as $91.98 \%, 95.92 \%$ and $99.31 \%$ for the respective years 1990, 2006 and 2017. The forest and cultivated land showed a reasonable user's and producer's accuracy; the producer's accuracy was relatively low for Grassland (73.64) in the year 1990 and confusion may be a result of the presence of low height forest stands in the forest as well as in the class boundaries. Built up sample data appeared to be well defined with the producer's accuracy of $100 \%$ and also with a user's accuracy of $100 \%$.

\subsection{Model Sensitivity Analysis}

SWAT CUP 2012 was used for sensitivity analysis. Table 8 presents the list of the parameters and their ranking with fitted values for the flows measurement at the 1KA11 Igawa maji gauge station. The curve number which indicates the runoff response of a catchment was found to be the most sensitive parameter followed by base flow alpha, groundwater delay, threshold depth of water, the shallow aquifer required for return flow (Table 8). The curve number and the base flow alpha are related to ground water, runoff and soil process and thus influence the stream flow in the watershed. The ALPHA_BF is a direct index of ground water flow response to changes in recharges. The Mbarali River sub-catchment has soil dominated with chromic Cambisols, dystric Nitosoils, dystric Regosols and Eutric Planosolsl that are possible for ground water recharge.

Table 7. Accuracy classification of ETM data of the year 1990, 2006 and 2017.

\begin{tabular}{|c|c|c|c|c|c|c|}
\hline \multirow[b]{2}{*}{ LULC } & \multicolumn{2}{|c|}{1990} & \multicolumn{2}{|c|}{2006} & \multicolumn{2}{|c|}{2017} \\
\hline & $\begin{array}{l}\text { Producer } \\
\text { accuracy } \\
(\%)\end{array}$ & $\begin{array}{c}\text { User } \\
\text { accuracy } \\
(\%)\end{array}$ & $\begin{array}{c}\text { Producer } \\
\text { accuracy } \\
(\%)\end{array}$ & $\begin{array}{c}\text { User } \\
\text { accuracy } \\
(\%)\end{array}$ & $\begin{array}{l}\text { Producer } \\
\text { accuracy } \\
(\%)\end{array}$ & $\begin{array}{c}\text { User } \\
\text { accuracy } \\
(\%)\end{array}$ \\
\hline Forest & 90.17 & 95.05 & 100 & 100 & 98.56 & 100 \\
\hline Woodland & 95.87 & 96.55 & 96.67 & 92.95 & 100 & 100 \\
\hline Bushland & 93.74 & 87.49 & 86.38 & 96.79 & 99.09 & 98.20 \\
\hline Grassland & 73.64 & 93.11 & 98.24 & 98.82 & 99.18 & 98.78 \\
\hline Wetland & 96.88 & 100 & 100 & 100 & 100 & 100 \\
\hline Cultivated land & 95.69 & 89.83 & 100 & 88.05 & 100 & 99.39 \\
\hline Built up area & 91.67 & 100 & 100 & 100 & 100 & 100 \\
\hline Overall accuracy (\%) & \multicolumn{2}{|c|}{91.98} & \multicolumn{2}{|c|}{95.92} & \multicolumn{2}{|c|}{99.31} \\
\hline Kappa statistic & \multicolumn{2}{|c|}{0.9} & \multicolumn{2}{|c|}{0.95} & \multicolumn{2}{|c|}{0.99} \\
\hline
\end{tabular}


Table 8. List of parameters and their ranking with fitted values for monthly flow.

\begin{tabular}{cccccc}
\hline \multicolumn{2}{c}{ Parameters } & Min_value & Max_value & Fitted value & Rank \\
\hline Name & Description & & & \\
\hline R_CN2.mgt & $\begin{array}{c}\text { SCS runoff curve } \\
\text { number (\%) }\end{array}$ & -0.300000 & 0.300000 & -0.295000 & $\mathbf{1}$ \\
V__ALPHA_BF.gw & $\begin{array}{c}\text { Base flow alpha } \\
\text { factor (days) }\end{array}$ & 0.000000 & 1.000000 & 0.268333 & 2 \\
V_GW_DELAY.gw & $\begin{array}{c}\text { Ground water } \\
\text { delay (days) }\end{array}$ & 30.000000 & 450.000000 & 93.699997 & $\mathbf{3}$ \\
V_GWQMN.gw & $\begin{array}{c}\text { Threshold depth of } \\
\text { water in the shallow } \\
\text { a quifer required for } \\
\text { return flow (mm) }\end{array}$ & 0.000000 & 2000.000000 & 1436.666626 & 4 \\
\hline
\end{tabular}

\subsection{SWAT Model Calibration and Validation Results}

The SWAT model was run for period of 20 years from 1990 to 2010, but then, the first 5 years were carefully taken for warming up the model, and calibration was performed for 10 years from 1990 to 2000 . Table 9 shows comparison between the simulated and measured flows during the calibration and validation period, its shown that there is a good agreement between the measured and simulated average monthly flows with Nash-Sutcliffe simulation efficiency (NSE) of 0.70 , Percentage Base (PBIA) 4.6 and coefficient of determination (R2) of 0.72 during calibration and Nash-Sutcliffe simulation efficiency (NSE) of 0.74 , Percentage Base (PBIA) 1.5 and coefficient of determination (R2) during validation. The observed monthly mean stream flow for the calibration period (1990-2000) in Igawa Maji station was $11.01 \mathrm{~m}^{3} / \mathrm{s}$, while the simulated was $10.5 \mathrm{~m}^{3} / \mathrm{s}$. The difference was not significant for the validation period (2001-2010) which shows that the observed monthly mean stream flow was $11.74 \mathrm{~m}^{3} / \mathrm{s}$ and simulated monthly mean flow was $11.56 \mathrm{~m}^{3} / \mathrm{s}$. The Predictive Probability Uncertainty (PPU) plots derived from running SUFI-2 within the SWAT CUP for 100 simulations are presented in Figure 4 and Figure 5, and both are at monthly time step.

Table 9 indicates the results of the flows simulation for the model performances that are adequately satisfactory during the calibration and validation period. This indicates that the model captures well the stream flows generated from the watershed. Therefore, the simulations results can be used in assessing the land use and cover impacts on stream flows.

\subsection{Assessment of Land Use and Land Cover Changes on Stream Flow}

The main aim of this study was to assess the impact of land use and land cover changes on stream flows of the Mbarali River catchment. The assessment was done in terms of the impact of land use and land cover changes on the seasonal stream flow and variations on the major components of stream flow including 


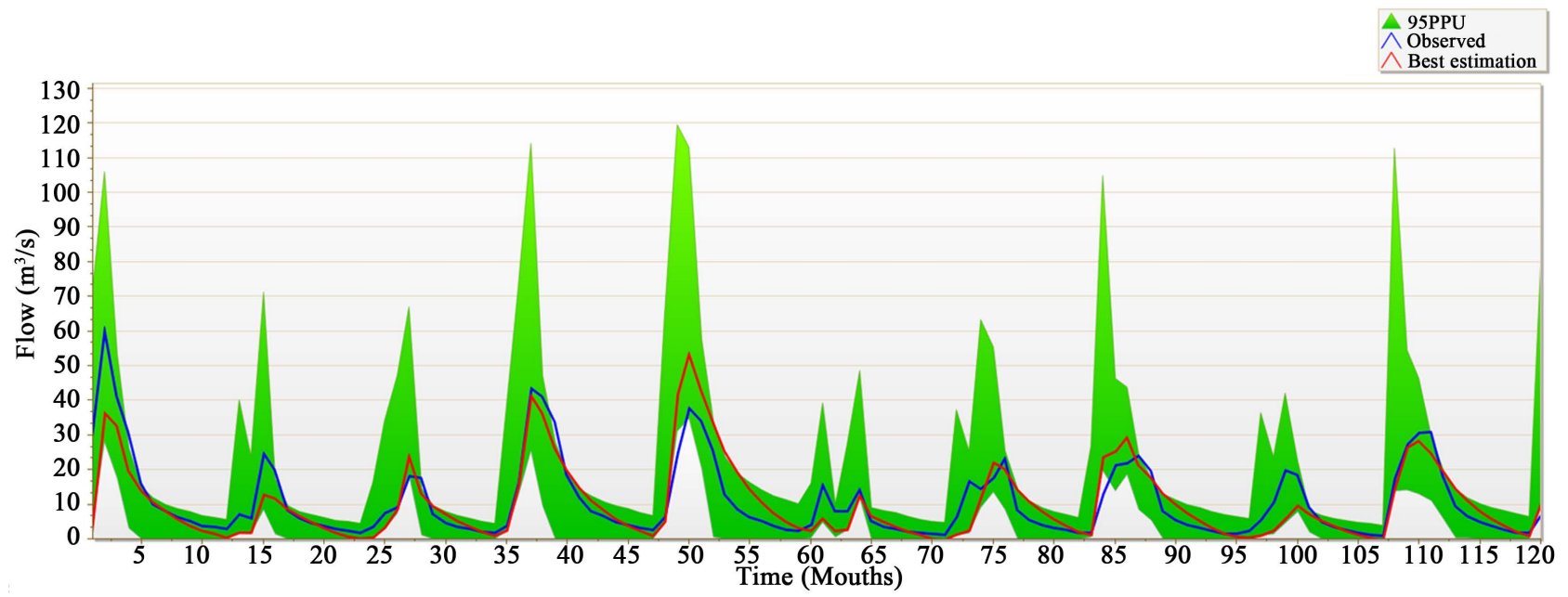

Figure 4. 95\% prediction uncertainty calibration hydrograph at Igawa station.

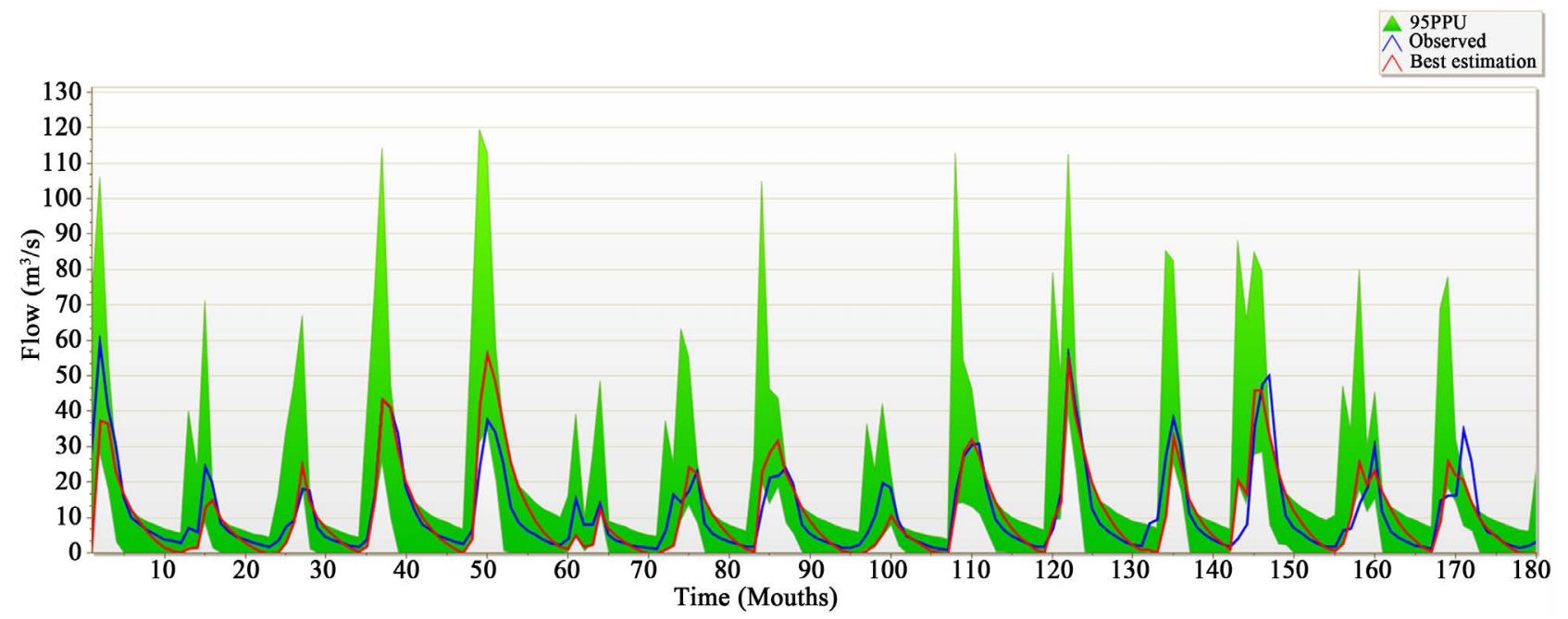

Figure 5. 95\% prediction uncertainty validation hydrograph at Igawa station.

Table 9. Comparison of simulated and observed monthly flow for calibration and validation simulations.

\begin{tabular}{ccccccc}
\hline \multirow{2}{*}{ Period } & \multicolumn{2}{c}{ Average monthly flow $\left(\mathrm{m}^{3} / \mathrm{s}\right)$} & & \multirow{2}{*}{$\mathbf{R}^{2}$} & NSE & PBIA \\
\cline { 2 - 5 } & Simulated & Observed & & & \\
\hline Calibration (1990-2000) & 10.5 & 11.01 & 0.72 & 0.70 & 4.6 \\
Validation (2001-2010) & 11.56 & 11.74 & 0.76 & 0.74 & 1.5 \\
\hline
\end{tabular}

water balance components during the period (1990, 2006 and 2017). Land use and land cover have a great influence on the rainfall-runoff process.

Table 10 presents the monthly mean flows for the seasonal cycle. The model was calibrated and validated using different land use data i.e. land use data for the periods of 1990, 2006 and 2017. Similarly the SWAT was run differently using land cover maps (1990, 2006 and 2017 maps) while other remaining 
Table 10. Mean monthly wet and dry month's stream flow and their variability.

\begin{tabular}{cccccc}
\hline \multicolumn{5}{c}{ Mean monthly flow $\left(\mathrm{m}^{3} / \mathrm{s}\right)$} \\
\hline Land use/cover map of 1990 & Land use/cover map of 2006 & Land use/cover map of 2017 \\
\hline $\begin{array}{c}\text { Wet months } \\
\text { (Jan, Feb, } \\
\text { March, April) }\end{array}$ & $\begin{array}{c}\text { Dry months } \\
\text { (Jun, July, } \\
\text { Aug, Sept) }\end{array}$ & $\begin{array}{c}\text { Wet months } \\
\text { (Jan, Feb, } \\
\text { March, April) }\end{array}$ & $\begin{array}{c}\text { Dry months } \\
\text { (Jun, July, } \\
\text { Aug, Sept) }\end{array}$ & $\begin{array}{c}\text { Wet months } \\
\text { (Jan, Feb, } \\
\text { March, April) }\end{array}$ & $\begin{array}{c}\text { Dry months } \\
\text { (Jun, July, } \\
\text { Aug, Sept) }\end{array}$ \\
\hline 27.68 & 0.24 & 27.82 & 0.21 & 28.09 & 0.20 \\
\hline
\end{tabular}

variables were kept constant during simulations in order to quantify the variability of stream flow due to the changes in land use and land cover. This technique presented the flows for both land use and land cover forms. Then, the results were compared and the discharge change during the season cycles, during the wettest months of stream flow were taken as January, February, March, April and the driest stream flow were in the months of June, July, August, and September. These were taken as means of estimating the effect of land use and land cover change on the stream flow. This has been indicated in Table 10. The mean monthly stream flow for wet months had increased from $27.68 \mathrm{~m}^{3} / \mathrm{s}$ to 28.09 $\mathrm{m}^{3} / \mathrm{s}$, while the dry season decreased $0.24 \mathrm{~m}^{3} / \mathrm{s}$ to $0.20 \mathrm{~m}^{3} / \mathrm{s}$ between the 1990-2017 periods due to the land use and land cover changes. Table 10 shows the mean monthly wet and dry month's stream flow for 1990, 2006 and 2017 land use and land cover maps and its variability (1990-2017).

Table 11 presents water balance components as simulated using the land use and land cover map for the three-land use land cover scenarios. The impacts of different land-use scenarios on the water balance components were analyzed at the catchment scale. The results indicate the change in land use land cover maps from the year 1990-2017 as a result of increase in surface runoff by $4.14 \mathrm{~mm}$ in the year 2006 and $5.29 \mathrm{~mm}$ in 2017, while the total water yield has shown to decrease by $0.07 \mathrm{~mm}$ in the year 2006 and decrease by $0.93 \mathrm{~mm}$ in the year 2017 . The cultivation of forest and the demand for agricultural land forced by urban development into settlements and infrastructure forms a sealed surface, which is adversely changing the partitioning of precipitation towards increasing surface runoff and reduced groundwater recharge [18] [19] [20].

The increase of the surface runoff is due to the fact that built-up areas features have high portion of impervious surfaces which hamper or sturdily decrease in water percolation and groundwater contribution to stream flow and enable an increase in surface runoff. This result comes to an agreement with the study done by [9] on the impacts of land-use and land-cover changes on flow regimes of the Usangu wetland and the Great Ruaha River. He observed that the change of the land use and land cover within the catchment causes an increase in runoff, decrease in base flow, increase in sediment deposit on the bank of the river and decrease of the width of the river channel.

Similarly, Table 11 shows that there is decrease in both actual evapotranspiration 
Table 11. Impact of water balance components under different land use/cover scenarios: Note that, Figures in Brackets are percentage change.

\begin{tabular}{ccccccc}
\hline YEAR & SURQ & GWQ & PERCQ & ET & SW & WYLD \\
\hline 1990 & 104.63 & 61.41 & 91.79 & 293.78 & 377.13 & 178.97 \\
2006 & $108.77(4.0)$ & $57.53(-6.3)$ & $88.25(-3.9)$ & $292.98(-0.3)$ & $378.34(0.3)$ & $178.9(0.0)$ \\
2017 & $114.06(9.0)$ & $53.51(-12.9)$ & $83.95(-8.5)$ & $290.67(-1.1)$ & $383.93(1.8)$ & $179.83(0.5)$
\end{tabular}

SURQ: Surface runoff contribution from stream flow from HRU (mm); GWQ: Ground water contribution to stream in watershed on day, month, year $(\mathrm{mm})$; PERCQ: Percolation in watershed (mm); ET: Actual Evapo-transpiration in watershed $(\mathrm{mm})$; SW: Soil water content $(\mathrm{mm})$; WYLD: Water yield $(\mathrm{mm})$.

and groundwater contribution to stream flows. These decreases are associated with the increasing trend in built-up areas for the entire Mbarali River sub-catchments. It is revealed that for the study area, there is an increase in built-up area by $31 \%$ between 1990 and 2006 and further an increase of 33\% between 2006 and 2017. This corresponds well with a declining trend of groundwater contribution to stream flow of $3.88 \mathrm{~mm}$ between 1990 and 2006 and 4.02 mm between 2006 and 2017, but an increase in urban area by 469 ha in 2006 and 502 ha in 2017, which leads to a strong decrease in actual evapotranspiration. The increase in surface runoff (Table 11) in the Mbarali River sub-catchment is considered by an increasing portion of built-up areas, which corresponds with the decreasing trend of percolation within the sub-catchment. This is reasonable due to the hydrological effect of impermeable surfaces on the increase of runoff and decrease in percolation.

The increase of agricultural land activities is associated with transformation on the land use and increase in water abstraction for irrigation purpose as a result of an increase of surface runoff following rainfall events. This can be explained by the crops that demand soil moisture for their growth. Crops need less soil moisture than forests; therefore, rainfall satisfies the soil moisture deficit in agricultural lands more quickly than in forests there by generating more surface runoff where the area under agricultural land is extensive. This causes variation in soil moisture and groundwater storage. Also, the extension results in the reduction of water infiltrating in to the ground. Therefore, discharge during dry months (which mostly comes from base flow) decreases, whereas the discharge during the wet months increases. These results demonstrate that the land use and land cover changes have a significant effect on infiltration rates, on the runoff production, and on the water retention capacity of the soil. These results are also supported by studies done by [4] and [10]. Over the selected window period the hydrological study on the land use and land cover changes within Mbarali River sub-catchment showed that the flow characteristics have changed, with an increase in surface flow and reduction of base flow.

\section{Conclusions and Recommendations}

In this study, satellite data and GIS were integrated with a hydrological model to 
assess the impacts of land use and land cover changes on the hydrology of the Mbarali River sub-catchment, Upper Great Ruaha sub-basin in Tanzania. Remote sensing and QGIS were used to map different land cover classes and to analyze spatial-temporal land cover appearance. These techniques were applied to assess the land cover change effects on the hydrology of the River sub-catchment. The impacts of the land cover change on hydrology were further analyzed using the hydrological model, SWAT and kappa statistics. The land use and land cover changes for the three snapshot years 1990, 2006 and 2017 were identified using TM and OLI_TIRS satellite images, respectively. The land use and land cover maps of the year 1990, 2006 and 2017 were produced and the accuracy assessments of the three maps were checked using the confusion Matrix.

Furthermore, data arrangement, sensitivity analysis, calibration, validation and evaluation of model performance were performed on the hydrological model, SWAT; these steps are done before the evaluation of the impacts of the land use and land cover changes on the stream flow of the sub-catchment was analyzed. The GIS environment in processing DEM uses land use and land cover, soil data layers and displaying model results. Based on the results, the following conclusions are drawn: from the land use and land cover analysis, it has been revealed that, there is substantialy change in land cover classes for the three years 1990, 2006 and 2017.

The cultivated land area tremendously increased from $25.69 \%$ in 1990 to $31.53 \%$ in 2006 and $43.57 \%$ in 2017 compared to other land classes. The extension of cultivated land and built-up area has an effect on the decrease of forest land. As such, the forest land which constituted $7.54 \%$ in 1990 was reduced to $5.51 \%$ in 2006 and $5.23 \%$ in 2017. Thus, by the overhead of forest land and other land cover types, the cultivated land includes areas for crop cultivation and the built-up area that are closely associated with the cultivated fields dynamically increased in the study (1990-2017). This could be the result of the increase in population which has triggered a huge need for other lands. As a result scarcity of cultivation land has been the major problem for farmers in the study area.

The sensitivity analysis using SWAT hydrological model has revealed four key parameters that govern the stream flow of the Mbarali River sub-catchment. In contrast, model calibration and validation have shown that the SWAT model simulated the flow reasonably well. Model performance during both the calibration and validation for the Mbarali River sub-catchment was found to be practically acceptable with Nash-Sutcliffe coefficients (ENS) values of 0.70 and 0.72 and coefficient of determination (R2) values of 0.74 and 0.76 for the calibration and validation respectively.

Following calibration and validation of the model, impacts of the land use and land cover changes on stream flow were also carried out. Land use and land cover changes were recognized to have major impacts on hydrological processes. The result of model for both periods of land use and land cover (1990, 2006 and 
2017) indicated that during the wet season, the mean monthly flow for 2006 land cover increased to $27.82 \mathrm{~m}^{3} / \mathrm{s}$ relative to that of 1990 land cover period while the mean monthly flow decreased by $0.21 \mathrm{~m}^{3} / \mathrm{s}$ during the dry season. The study further examined the impact of land use and land cover on catchment water balance component. It was revealed that surface runoff increased by $3.9 \%$ in the 2006 and $9.01 \%$ in the year 2017, while the ground water contribution to stream flows decreased by $6.3 \%$ and $12.86 \%$ in both 2006 and 2017 respectively. Similarly, the total water yield, actual evapotranspiration, percolation below the root zone commonly called as groundwater recharge (PERC) which could be an inflow for flow at downstream of the sub-catchment both has been shown to decrease.

Within the Upper Great Ruaha sub-catchment of the Rufiji basin, the study recommends to investigate-different catchment management options, that will conserve water resource base, whereas upgrading the socio-economic status of the population. Hence, various advance scenarios should be explored and the best alternative effected for the Upper Great Ruaha sub-catchment. A proposed management approach should be planned to conserve the vegetation. This is suggested to improve the supply of water for the whole Mbarali River sub-catchment during both wet and dry periods.

\section{Acknowledgements}

This work was carried out under the Future Climate for Africa UMFULA project, with a financial support from the UK Natural Environment Research Council (NERC), grant ref. No: NE/M020037/1, and the UK Government's Department for International Development (DfID).

\section{Conflicts of Interest}

The authors declare no conflicts of interest regarding the publication of this paper.

\section{References}

[1] IPCC (2013) The Physical Science Basis-Summary for Policymakers. Contribution of WG1 to the Fourth Assessment Report of the Intergovernmental Panel on Climate Change. http://www.ipcc.ch/ipccreports/ar4-wg1.htm

[2] IPCC (2014) The Physical Science Basis-Summary for Policymakers. Contribution of WG1 to the Fourth Assessment Report of the Intergovernmental Panel on Climate Change. http://www.ipcc.ch/ipccreports/ar4-wg1.htm

[3] Piao, S., Friedlingstein, P., Ciais, P., de Noblet-Ducoudre, N., Labat, D. and Zaehle, S. (2007) Changes in Climate and Land Use Have a Larger Direct Impact Than Rising $\mathrm{CO}_{2}$ on Global River Runoff Trends. PNAS, 104, 15242-15247. https://doi.org/10.1073/pnas.0707213104

[4] Balthazar, V., Vanacker, V., Molina, A. and Lambin, E.F. (2015) Impacts of Forest Cover Change on Ecosystem Services in High Andean Mountains. Ecological Indicators, 48, 63-75. https://doi.org/10.1016/j.ecolind.2014.07.043 
[5] DeFries, R. and Eshleman, K.N. (2004) Land-Use Change and Hydrologic Processes: A Major Focus for the Future. Hydrological Processes, 18, 2183-2186. https://doi.org/10.1002/hyp.5584

[6] Schulze, R.E. (2000) Modelling Hydrological Responses to Land Use and Climate Change: A Southern African Perspective. Ambio Journal of Human Environment, 29, 12-22. https://doi.org/10.1579/0044-7447-29.1.12

[7] Zhang, L., Dawes, W.R. and Walker, G.R. (2001) Response of Mean Annual Evapotranspiration to Vegetation Changes at Catchment Scale. Water Resources Research, 37, 701-708. https://doi.org/10.1029/2000WR900325

[8] Brown, A.E., Zhang, L., McMahon, T.A., Western, A.W. and Vertessy, R.A. (2005) A Review of Paired Catchment Studies for Determining Changes in Water Yield Resulting from Alterations in Vegetation. Journal of Hydrology, 310, 28-61. https://doi.org/10.1016/j.jhydrol.2004.12.010

[9] Kashaigili, J.J. (2008) Impacts of Land-Use and Land-Cover Changes on Flow Regimes of the Usangu Wetland and the Great Ruaha River, Tanzania. Physics Chemistry Earth, 33, 640-647. https://doi.org/10.1016/j.pce.2008.06.014

[10] Kashaigili, J.J. and Majaliwa, A.M. (2013) Integrated Assessment of Land Use Land Cover Changes on Hydrological Regime of the Malagarasi River Catchment in Tanzania. Journal of Physics and Chemistry of the Earth, 35, 730-741. https://doi.org/10.1016/j.pce.2010.07.030

[11] Tanzania National Bureau of Statistics (2013) Statistics for Development.

[12] http://www.glovis.usgs.gov.

[13] https://reverb.echo.nasa.gov.

[14] Kashaigili, J.J., McCartney, M.P., Mahoo, H.F., Lankford, B.A., Mbilinyi, B.P., Yawson, D.K. and Tumbo, S.D. (2006) Use of a Hydrological Model form Environmental Management of the Usangu Wetlands, Tanzania. Research Report No. 104. International Water Management Institute, Colombo Sri Lanka, 48 p.

[15] Li, R.Q., Dong, M., Cui, J.Y., Zhang, L.L., Cui, Q.G. and He, W.M. (2007) Quantification of the Impact of Land-Use Changes on Ecosystem Services: A Case Study in Pingbian County, China. Environmental Monitoring and Assessment, 128, 503-510. https://doi.org/10.1007/s10661-006-9344-0

[16] Arnold, J.G., Moriasi, D.N., Gassman, P.W., Abbaspour, K.C., White, M.J., Srinivasan, R., Santhi, C., Harmel, R.D., van Griensven, A., Van Liew, M.W. and Kannan, M.K. (2012) Model Use, Calibration, and Validation. American Society of Agricultural and Biological Engineers, 55, 1491-1508.

[17] Abbaspour, K.C., Yang, J., Maximov, I., Siber, R., Bogner, K., Mieleitner, J. and Srinivasan, R. (2007) Modelling Hydrology and Water Quality in the Prealpine/Alpine Thur Watershed Using SWAT. Journal of Hydrology, 333, 413-430. https://doi.org/10.1016/j.jhydrol.2006.09.014

[18] Mustard, J. and Fisher, T. (2004) Land Use and Hydrology. Land Change Science: Observing Monitoring and Understanding Trajectories of Change on the Earth's Surface. Springer Netherlands, 257-276.

[19] Shanahan, P. and Jacobs, B.L. (2007) Ground-Water and Cities. In: Novotny, V. and Brown, P.R., Eds., Cities of the Future: Towards Integrated Sustainable Water and Landscape Management, IWA Publishing, London, 122-140.

[20] Jat, M.L., Gathala, M.K., Ladha, J.K., Saharawat, Y.S., Jat, A.S., Kumar, V., Sharma, S.K., Kumar, V. and Raj, G. (2009) Evaluation of Precision Land Leveling and 
Double Zero-Till Systems in the Rice-Wheat Rotation: Water Use, Productivity, Profitability and Soil Physical Properties. Soil and Tillage Research, 105, 112-121. https://doi.org/10.1016/j.still.2009.06.003 